\title{
Regulatory Region Amplification
}

National Cancer Institute

\section{Source}

National Cancer Institute. Regulatory Region Amplification. NCI Thesaurus. Code C148648.

An increase in the copy number of a region containing a regulatory sequence for a gene. 